\title{
H. IRDCP
}

\section{International Conference on Environmental, Agriculture and Rural Development (EARD-2020)}

October 17-18, 2020

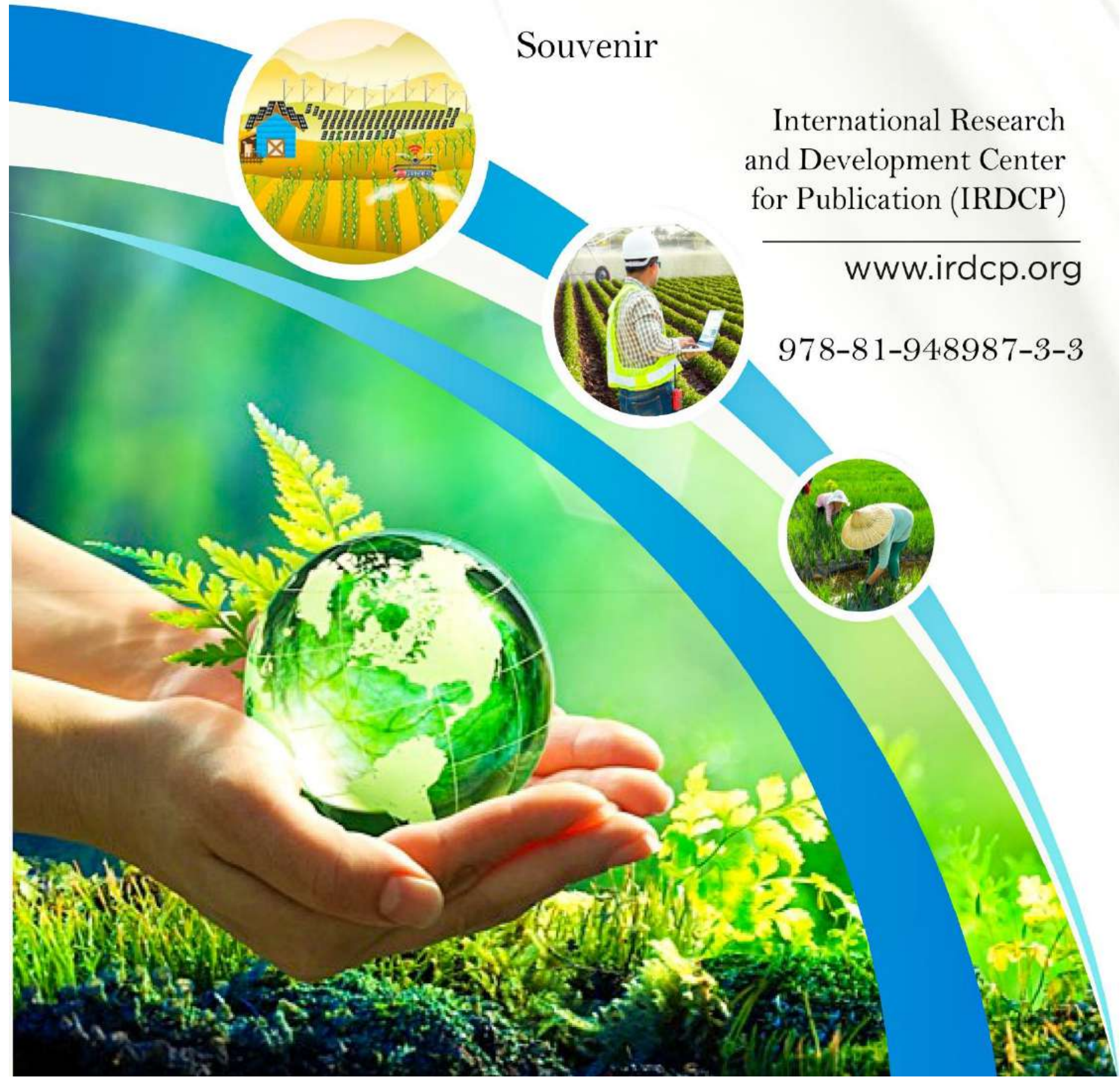




\section{International Conference}

\section{on}

Environmental, Agriculture and Rural Development

$$
\begin{gathered}
\text { (EARD-2020) } \\
\text { Oct 17-18, } 2020
\end{gathered}
$$

Copyright (C 2020 International Research and Development Center for Publication

DOI: $\underline{10.22161 / \text { conf.eard.oct.2020 }}$

ISBN: 978-81-948987-3-3

\section{Publisher}

\section{IRDCP}

Email: irdcp.publication@gmail.com |conference.irdcp@gmail.com

Web: https://irdcp.org/ 


\section{$\underline{\text { About IRDCP }}$}

International Research and Development Center for Publication (IRDCP) is a nonprofit organization for promoting research and development around the world. IRDCP is the bridge between the quality publisher and researchers. It provides the platform to researchers and academicians for publication in the Scopus Indexed Journals, SCI Journals, Web of Science Journals, UGC Approved Journals, NAAS Rated Journals, Google Scholar Indexed Journals and other good quality DOI journals.

IRDCP is also a partner organization for publication in conference proceedings. We organize the International conferences for publication in SCOPUS indexed and other refereed journals as per the requirement of the authors of the manuscripts. The manuscripts submitted to IRDCP should be plagiarism free and well coherent in all sense.

The scope of publication with the IRDCP covers all type of review and research manuscripts including the Exploratory \& Explanatory Research, Descriptive \& Theoretical Research, Applied Research \& Action Research, Cross-Sectional Research, Quantitative \& Qualitative Research in the field of engineering \& technology, agriculture \& environmental, Social science \& Humanities, Literature \& Education development, Medical \& Health Science.

\section{The vision of IRDCP :}

IRDCP endeavors to promote global excellence in the field of research \& development through diligent applications of advanced technology for the holistic development of society. Also, IRDCP is committed to motivate and persuade the researchers to take up the projects for the continuous development of human society and make this world a better place to live in. The IRDCP has a steadfast commitment be the fulcrum of the ocean of knowledge around which efforts of researchers move about. 


\section{$\underline{\text { About Conference }}$}

\section{International Conference on Environmental, Agriculture and Rural Development (EARD-2020)}

During the worldwide lockdown due to COVID 19 pandemic, a lot of important activities have come to a halt. However, when we look at the brighter side, all of us have more time for adding to our knowledge and insights.

With this aim, to keep contributing to learning and motivation International research and development Center for publication is going to organize a two-day International Conference with the title " International Conference on Environmental, Agriculture and Rural Development (EARD-2020)" on Oct 17-18, 2020 through online mode.

We hope, this online mode of the conference in COVID-19 pandemic will be an appreciable step in promoting the research activities and new information between researchers, developers, students, academicians and practitioners working in and around the world by keeping the social distance in view to stop the spread of COVID-19 disease. This conference aims is to present the current researches being carried out in the field of social science and education development around the globe.

Prospective authors from academia as well as industry are invited to submit their abstracts that illustrate original/unpublished works and industrial applications describing advances and significant innovations in the field. 


\section{International Advisory Committee}

- Muvunyi Ronaldo, Taiyuan University of Technology, China

- Sahar Mirzaei, Horticultural Science Research Institute, Agricultural Research, Education and Extension Organization (AREEO), Mahallat, Iran.

- Professor Tamuno-Omi Godwin Dappa, Federal University Wukari, Nigeria

- Dr. Etim Nse Akpan, Federal University Wukari, Nigeria

- Dr. Elechi Felix Aja, Ebonyi State University, Abakaliki, Nigeria

- Dr. Mehmet Firat Baran, Associate Prof. , Faculty of Technology, Department of Energy Systems Engineering, Altinsehir, Adiyaman, Turkey

- Dr. Alexandra D. Solomou, Agricultural Engineer, Hellenic Agricultural Organization "DEMETER", Institute of Mediterranean and Forest Ecosystems, Terma Alkmanos, Ilisia, 11528, Athens, Greece.

- Dr. A. Heidari, Faculty of Chemistry, California South University (CSU), Irvine, California, USA

- Dr. Abd El-Aleem Saad Soliman Desoky, Faculty of Agriculture, Sohag University, Egypt

- Dr. Ekrem BÖLÜKBAŞI, Molecular biology and Biotechnology, Amasya University, Turkey

- Assoc. Prof Dr. Mehmet Karakaş, General biology and zoology, Physiology, Ankara University, Turkey 


\section{Message}

I am extremely pleased to share that International Research and Development Center for Publication (IRDCP) is organizing a two days International Conference on Environmental, Agriculture and Rural Development (EARD-2020) on Oct 17-18, 2020.

I am sure the state of art lectures from the invited experts and the research findings of researchers, academicians, utility engineers will enrich the knowledge of all the participants. It will provide an excellent opportunity for students to learn new ideas.

I offer my best wishes to the whole team of the organizing committee, the participants, and volunteers for the grand success of the conference.

Dr. Kiran

Convenor EARD-2020 


\section{Message}

I am happy to know that International Research and Development Center for Publication (IRDCP) is organizing a two days International Conference on Environmental, Agriculture and Rural Development (EARD-2020) on Oct 17-18, 2020. I am sure that, this conference would provide an ideal platform for the academicians, scholars and experts to present and exchange their research findings and Ideas.

I wish the conference a great success.

Dr. Praveen Kumar Jain 


\section{INDEX}

On farm and on station performance of Binadhan-17 under varied planting time

Shampa Rani Ghosh, Sushan Chowhan, Snigdha Roy, Dinesh Chandra Roy, Md. Khan Jahan Ali, Kamrun Nahar, Md. Moshiur Rahman, Md. Imdadul Hoque

2

Food from By Product: Development and Quality Evaluation of Ready to Eat Cooked Turkey Meat Rolls Incorporated with Turkey Gizzards M. Anna Anandh

Quality and Acceptability of Emulsion and Ground Batter Meat Patties from Turkey (Meleagris gallopavo) Meat

M. Anna Anandh

Development and Quality Evaluation of Meat Based Seasoning Fryums (Meat Vadam) Incorporated with Goat Meat Emulsion and Ground Goat Meat

M. Anna Anandh

Bio-pesticides--a new era for control of Mealy bug (Maconellicoccus

hirsutus Green) on som plant (Machilus bombycina King) and environmental sustainability

Sunil Kumar Ghosh

13

Evaluation of Puf locus targeted PCR for easy identification of Saprolegnia parasitica

Khangembam Victoria Chanu, Dimpal Thakuria, Vinita Pant, Sweta Bisht 
Control of Insect pests of Mung bean (Vigna radiata L. Wilczek) using

\section{Plant extracts}

Anand Kumar Prajapat, Lekhu Gehlot

18

Rice yield and soil fertility status at harvest as influenced by integrated nitrogen management

Harish Shenoy and Siddaraju. M. N.

20

Chemical composition of essential oils of Rhus tripartita in Algeria

Benlembarek Khaoula, Lograda Takia, Ramdani Messaoud and Belguidoum Amina

Biomonitoring of metal trace elements by epiphytic lichen Xanthoria parietina in Bejaia area (Northern Algeria)

Belguidoum Amina, Logradatakia, Benlembarek Khaoula, and Ramdani Messaoud 

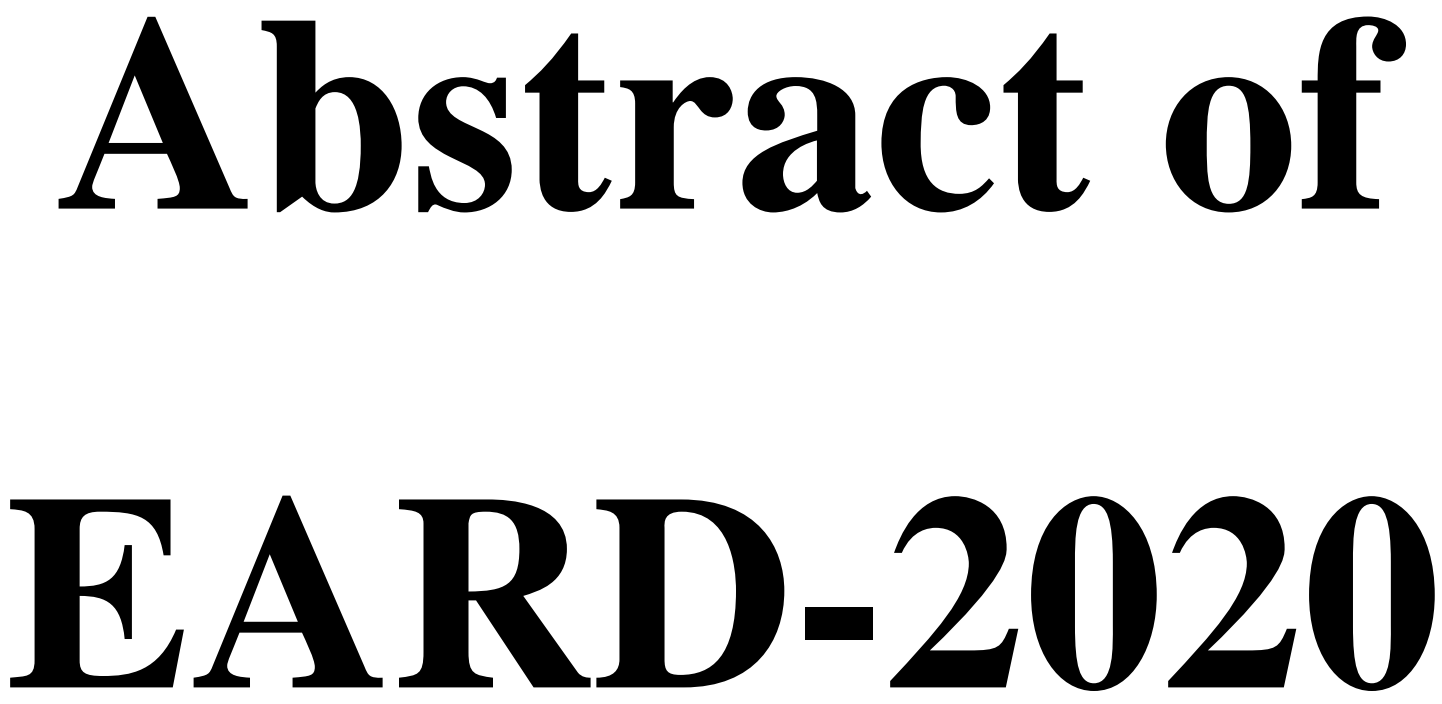


\title{
On farm and on station performance of Binadhan-17 under varied planting time
}

\author{
Shampa Rani Ghosh ${ }^{1}$, Sushan Chowhan ${ }^{2 *}$, Snigdha Roy ${ }^{3}$, Dinesh Chandra Roy ${ }^{3}$, Md. Khan \\ Jahan $\mathrm{Ali}^{4}$, Kamrun Nahar ${ }^{4}$, Md. Moshiur Rahman ${ }^{4}$, Md. Imdadul Hoque ${ }^{3}$
}

${ }^{1}$ Planning and Development Cell, Bangladesh Institute of Nuclear Agriculture, Mymensingh2202, Bangladesh

${ }^{2}$ Adaptive Research and Extension Division, Bangladesh Institute of Nuclear Agriculture, Substation, Ishurdi, Pabna-6620, Bangladesh.

${ }^{3}$ Plant Breeding Division, Bangladesh Institute of Nuclear Agriculture, Mymensingh-2202, Bangladesh

${ }^{4}$ Plant Breeding Division, Bangladesh Institute of Nuclear Agriculture, Sub-station, Ishurdi, Pabna-6620, Bangladesh

*Email Id: $\underline{\text { sushan04@yahoo.com }}$

\begin{abstract}
Binadhan-17 is a high yielding variety of aman rice (mainly grown by rainfed). Due to it's extensive popularity; rice growers are cultivating it in boro season (in winter through irrigation) also. Considering the above circumstance, an on farm and on station research trial was conducted at BINA sub-station, Magura and farmer's field of Sattyapur Sadar, Magura during November 2019 to May 2020 to observe the effect of variety, planting dates and their interaction. Factorial RCBD was applied for experimentation. Two varieties viz. Binadhan-17 $\left(\mathrm{V}_{1}\right)$, BRRI dhan58 $\left(\mathrm{V}_{2}\right)$ and three sowing time viz. $30^{\text {th }}$ November $\left(\mathrm{T}_{1}\right), 10^{\text {th }}$ December $\left(\mathrm{T}_{2}\right), 20^{\text {th }}$ December $\left(\mathrm{T}_{3}\right)$ were applied as treatments. Seedlings were transplanted at 35 DAS. Phenological, yield and maturity related data were statistically analyzed by Statistix 10. Interaction effect of the above factors at on farm indicated that, significantly longest plant height $(94.33 \mathrm{~cm})$ was observed at $\mathrm{T}_{3} \times \mathrm{V}_{2}$ and shortest $(80.60 \mathrm{~cm})$ with $\mathrm{T}_{2} \times \mathrm{V}_{1}$ combination. Highest panicle length $(23.87 \mathrm{~cm})$ was recorded at $T_{2} \times V_{2}$ and lowest $(21.80 \mathrm{~cm})$ by treatment combination $T_{1} \times V_{2}$. Total number of filled grains/panicle was most (162.87) in $T_{1} \times V_{1}$ whereas, least (107.00) was found in $T_{3} \times V_{2}$.
\end{abstract}


Greater number (36.00) of sterile grains/panicle was noticed on $T_{3} \times V_{1}$; contrary, lesser sterile grains (13.73) were found with $T_{2} \times V_{2}$. Thousand grain weight was more $(24.91 \mathrm{~g})$ in $\mathrm{T}_{1} \times \mathrm{V}_{1}$ and less $(23.20 \mathrm{~g})$ in $\mathrm{T}_{2} \times \mathrm{V}_{2}$. Treatment aggregate $\mathrm{T}_{1} \times \mathrm{V}_{1}$ had a lengthy life cycle (159.33 days to maturity) but, relatively short life cycle (149.97 days) was seen with $\mathrm{T}_{3} \times \mathrm{V}_{2}$. Maximum grain yield $(7.70 \mathrm{t} / \mathrm{ha})$ was produced by $\mathrm{T}_{2} \times \mathrm{V}_{1}$ and minimum $(5.74 \mathrm{t} / \mathrm{ha})$ by $\mathrm{T}_{1} \times \mathrm{V}_{1}$ treatment combination. Findings of on station revealed that, longest plant height $(98.33 \mathrm{~cm})$ was seen in treatment combination $\mathrm{T}_{3} \times \mathrm{V}_{2}$ and shortest $(78.86 \mathrm{~cm})$ with $\mathrm{T}_{1} \times \mathrm{V}_{1}$; which was statistically significant. Larger and smaller panicle length was observed in $\mathrm{T}_{3} \times \mathrm{V}_{2}(24.43 \mathrm{~cm})$ and $\mathrm{T}_{1} \times \mathrm{V}_{2}$ $(21.33 \mathrm{~cm})$ respectively. Filled number of total spikelets/panicle were more at $\mathrm{T}_{3} \times \mathrm{V}_{1}(158.13)$ and less in $T_{1} \times V_{1}$ (120.87). Number of unfilled spikelets/panicle were greater with $T_{2} \times V_{1}$ (53.53) and lesser with $\mathrm{T}_{1} \times \mathrm{V}_{2}$ (21.80). Heaviest and lightest 1000 seed weight was obtained from $\mathrm{T}_{1} \times \mathrm{V}_{1}(24.69 \mathrm{~g})$ and $\mathrm{T}_{2} \times \mathrm{V}_{2}$ (23.33 g). Treatment aggregate $\mathrm{T}_{1} \times \mathrm{V}_{1}$ (158.00 days) required longer days to mature; contrary, statistically identical duration was noticed with $\mathrm{T}_{2} \times \mathrm{V}_{2}$ (147.20 days) and $\mathrm{T}_{3} \times \mathrm{V}_{2}$ (145.43 days) which matured much shorter. Maximal grain yield was generated by $\mathrm{T}_{2} \times \mathrm{V}_{1}(7.41 \mathrm{t} / \mathrm{ha})$ and $\mathrm{T}_{1} \times \mathrm{V}_{2}$ yielded $5.94 \mathrm{t} / \mathrm{ha}$ which was significantly minimal among the treatment combinations. From the above on farm and on station investigation it can be concluded that, sowing of Binadhan-17 at $10^{\text {th }}$ December $\left(\mathrm{T}_{2}\right)$ may give optimum yield which might be economically viable in the context of Magura region.

\section{Keywords - Binadhan-17, Magura, Sowing time, Yield.}

\section{References:}

[1] Anonymous (2016). Annual Report of Bangladesh Rice Research Institute 2014-2015, BRRI, Gazipur 1701, Bangladesh, 278 pp.

[2] Chowhan, S., Haider, M. R., Hasan, A. F. M. F., Hoque, M. I., Kamruzzaman, M. and Gupta, R. (2017). Comparative on farm performance of five modern rice varieties with two local cultivars. Journal of Bioscience and Agriculture Research, 13(01), 1074-1086. https://doi.org/10.18801/jbar.130117.131

[3] Karim, M., Kashem, M. A., Huda, A., Aziz, M. A. and Goswami, B. K. (2019). Effect of Different Doses of Urea on the Yield of Boro Rice Varieties in Haor Areas of Bangladesh. Asian Plant Research Journal, 3(2), 1-9. https://doi.org/10.9734/aprj/2019/v3i230061 
[4] Khatun, S., Mondal, M. M. A., Khalil, M. I., Roknuzzaman, M. and Mollah, M. M. I. (2020). Growth and Yield Performance of Six Aman Rice Varieties of Bangladesh. Asian Research Journal of Agriculture, 12(2), 1-7. https://doi.org/10.9734/arja/2020/v12i230077

[5] Nath, A., Kashem, M. A. and Ali, S. (2018). Growth and Yield Performance of Boro Rice (BRRI dhan58) Under Different Fertilizer and Agronomic Management in Wetland. International Journal of Agricultural Research, 13, 53-57. https://doi.org/10.3923/ijar.2018.53.57

[6] Rakib, A., Akter, K. T., Khanom, M. S. R., Rahman, M. S. and Alam, A. B. M. S. (2019). Performance of Binadhan-17 compare to BRRIdhan28, BRRIdhan29, BRRIdhan81 and BRRIdhan89. International Journal of Natural and Social Sciences, 6(2), 22-26. 


\title{
Food from By Product: Development and Quality Evaluation of Ready to Eat Cooked Turkey Meat Rolls Incorporated with Turkey Gizzards
}

\author{
M. Anna Anandh
}

\author{
Tamil Nadu Veterinary and Animal Sciences University (TANUVAS), \\ Department of Livestock Products Technology, Veterinary College and Research Institute, \\ Tirunelveli - 627 358, Tamil Nadu, India. \\ Email Id: drannaanandh@gmail.com
}

\begin{abstract}
Turkeys (Meleagris gallopavo) occupies an important position next to chicken, ducks, guinea fowls and quails. Turkeys are reared and slaughtered mainly for meat, the byproducts that are emanated from slaughtered turkey birds are also of good value. Gizzard is one of the principal edible by - product and the texture of gizzard is tough and rubbery due to their characteristic muscular construction. Gizzards usually less preferred by the consumer due to its peculiar flavor and texture. In this perspective, it is necessary to evolve appropriate technologies to convert the tough, less palatable and more perishable gizzards in to convenience, attractive and more acceptable novel ready to eat cooked meat products. Hence, a study was conducted to focus on greater value addition to turkey gizzards through preparation of ready to eat cooked turkey meat rolls from combination of turkey meat with $25 \%$ and $50 \%$ turkey gizzards. The turkey meat rolls prepared from $100 \%$ turkey meat was used as control. Significantly $(\mathrm{P}<0.05)$ higher $\mathrm{pH}$, product yield, moisture retention, moisture, protein and fat contents and significantly $(\mathrm{P}<0.05)$ lower diameter shrinkage, shear force and drip loss values were observed in $25 \%$ turkey gizzard incorporated ready to eat cooked turkey meat rolls then 50\% turkey gizzards incorporated ready to eat cooked turkey meat rolls. The sensory attributes scores for appearance and colour, flavour, juiciness, texture, binding and overall acceptability were significantly $(\mathrm{P}<0.05)$ higher for $25 \%$ turkey gizzard incorporated ready to eat cooked turkey meat rolls as compared to $50 \%$ turkey gizzards incorporated ready to eat cooked turkey meat rolls. All physico
\end{abstract}


- chemical parameters and sensory evaluation scores of $25 \%$ turkey gizzards incorporated ready to eat cooked turkey meat rolls were comparable with control. The ready to eat turkey meat rolls prepared by using $25 \%$ turkey gizzards had significantly superior physico - chemical characteristics and higher sensory acceptability as compared to 50\% turkey gizzards incorporated ready to eat turkey meat rolls. Therefore, turkey gizzards can be successfully used at $25 \%$ level for preparation of acceptable quality of comminuted ready to eat cooked turkey meat rolls.

\section{Keywords - Acceptability, Gizzard, Meat, Ready to eat, Rolls, Quality}

\section{References:}

[1] Anjaneyulu, A.S.R. \& Kondaiah, N. (1990). Quality of buffalo meat nuggets and rolls containing edible by products. Indian Journal of Meat Science, 3: 95 - 99.

[2] Anna Anandh, M., Radha, K., Lakshmanan, V. \& Mendiratta, S.K. (2008). Development and quality evaluation of cooked buffalo tripe rolls. Meat Science, 80:1194 - 119.

[3] Aydar, A.Y., Gürel, B. \& Kayaard1, S. (2018). Development of chicken rolls recipe using response surface methodology. Italian Journal of Food Science, 30:553 - 567.

[4] Chen, T.C. \& Stinson, R.S. (1983). Scanning electron microscope studies on chicken gizzard structure as affected by cooking. Poultry Science, 62: 2011- 2016.

[5] Devatkal, S. \& Mendiratta, S.K. (2001). Use of calcium lactate with salt phosphate and alginate calcium gel in restructured pork rolls. Meat Science, 58:371-379.

[6] Lin, K.W. \& Keeton, J.T. (1994). Determination of optimum particles size for low fat pre cooked ground beef patties. Journal Muscle Foods, 12: 53 - 76.

[7] Lingaiah \& Reddy, P. (2001). Quality of chicken meat patties containing skin and giblets. Journal of Food Science and Technology, 38: 400 - 401.

[8] Raharjo, S., Dexter, D. R., Worfel, R.C, Sofos, J.N, Solomon, M.B. \& Shultz, G.W. (1995). Quality characteristics of restructured beef steaks manufactured by various techniques. Journal of Food Science, 60: 68 - 71. 
[9] Reddy, P.K. \& Vijayalakshmi, K. (1998). Effect of incorporation of skin, gizzard, heart and yolk on the quality of frozen chicken meat sausages. Journal of Food Science and Technology, 35(3): 276-278. 


\title{
Quality and Acceptability of Emulsion and Ground Batter Meat Patties from Turkey (Meleagris gallopavo) Meat
}

\author{
M. Anna Anandh \\ Tamil Nadu Veterinary and Animal Sciences University (TANUVAS), \\ Department of Livestock Products Technology, Veterinary College and Research Institute, \\ Tirunelveli - 627 358, Tamil Nadu, India. \\ Email Id: drannaanandh@gmail.com
}

\begin{abstract}
Commercial turkey (Meleagris gallopavo) farming is becoming popular in India and farmers started to show interest in rearing turkey birds. Popularization of turkey meat and meat products through efficient utilization process is necessary to upgrade this back yard activity in to a commercial business. Development of value added products from the turkey meat would be the most profitable way of utilization turkey meat. In this perspective, a study was conducted to develop and assess the quality and acceptability of meat patties from turkey meat. Significantly $(\mathrm{P}<0.05)$ higher $\mathrm{pH}$, moisture retention, product yield, water holding capacity and moisture contents were observed in turkey meat emulsion based meat patties as compared to turkey meat ground batter based meat patties. The dimensional parameters viz. decrease in diameter and percent shrinkage values were significantly $(\mathrm{P}<0.05)$ higher in turkey ground batter meat patties as compared to turkey meat emulsion patties whereas percent gain in height value was significantly $(\mathrm{P}<0.05)$ higher in turkey meat emulsion patties. Protein and fat contents of turkey meat emulsion based meat patties and turkey meat ground batter based meat patties did not differ sufficiently. Turkey meat emulsion based meat patties had significantly $(\mathrm{P}<0.05)$ higher sensory scores then ground batter based turkey meat patties. The meat patties prepared by using turkey meat emulsion were rated highly acceptable as compared to ground turkey meat patties.
\end{abstract}

Keywords - Acceptability, Batter, Emulsion, Meat, Turkey, Quality, Patties. 


\section{References:}

[1] Anjaneyulu, A.S.R, Sharma, N. \& Kondaiah, N. (1989). Evaluation of salt, polyphosphates and their blend sat different levels on physic - chemical properties of buffalo meat patties. Meat Science, 25: 293 - 306.

[2] Baldwin, R.E., Korschgen, B.M., Vandepopuliere, J.M. \& Russell, W.D. (1975). Palatability of ground turkey and beef containing soy. Poultry Science, 54:1102.

[3] Berry, B.W. (1992). Low Fat Level Effects on Sensory, Shear, Cooking, and Chemical Properties of Ground Beef Patties. Journal of Food Science, 57: 537 - 540.

[4] Cross, H.R., Berry, B.W. \& Wells, L.H. (1980). Effects of fat level and source on the chemical, sensory and cooking properties of ground beef patties. Journal of Food Science, 45: 791-793.

[5] Chatli, M.K., Sharma, D.K., Biswas, A.K. \& Shaoo, J. (2010). Quality characteristics of turkey meat patties formulated with tapioca Starch. Journal of Poultry Science, 45: 311 314.

[6] El-Magoli, S.B., Laroia, S. \& Hansen, P.M.T. (1996). Flavor and texture characteristics of low fat ground beef patties formulated with whey protein concentrate. Meat Science, 42: 179 $-193$.

[7] Eyas, A.M., Anjaneyulu, A.S.R., Sathu, T., Thomas, R. \& Kondaiah, N. (2007). Effect of different binders on the quality of enrobed buffalo meat cutlets and their shelf life at refrigeration storage $\left(4 \pm 1^{\circ} \mathrm{C}\right)$. Meat Science, $75: 451-459$.

[8] He, Y. \& Sebranek, J.G. (1996). Functional Protein Components in Lean Finely Textured Tissue from Beef and Pork. Journal of Food Science, 61: 1155 - 1159.

[9] Moon, C.T., Yancey, J.W.S., Apple, J.K. Hollenbeck, J.J., Johnson, T.M. \& Winters, A.R. (2016). Quality characteristics of fresh and cooked ground beef can be improved by the incorporation of lean finely - textured beef (LFTB). Journal of Food Quality, 39: 465 - 475. 


\title{
Development and Quality Evaluation of Meat Based Seasoning Fryums (Meat Vadam) Incorporated with Goat Meat Emulsion and Ground Goat Meat
}

\author{
M. Anna Anandh \\ Tamil Nadu Veterinary and Animal Sciences University (TANUVAS), \\ Department of Livestock Products Technology, Veterinary College and Research Institute, \\ Tirunelveli - 627 358, Tamil Nadu, India. \\ Email Id: drannaanandh@gmail.com
}

\begin{abstract}
Left over rice vathals or vadams is a sun dried product which can be stored for over a year. Vadam is traditionally made using left over rice. Most of the vadam available in the market are mainly based of cereals which are high in calorie and low in protein contents. Incorporation of animal proteins in such snack type food products can improve the nutritional quality especially with respect to amino acid composition, flavor and taste. In this perspective, a study was conducted for the preparation of ready to fry meat based seasoning fryums (meat vadam) from combination of goat meat (50\%) and rice flour (50\%). Two types of ready to fry meat based seasoning fryums (meat vadam) were developed viz. ground goat meat based ready to fry seasoning fryums (meat vadam) and goat meat emulsion based ready to seasoning fryums (meat vadam) and their quality and acceptability were evaluated. Control ready to fry seasoning fryums contained $100 \%$ rice flour without goat meat. Other ingredients used in the formulation viz. common salt $(2.5 \%)$, green chili paste $(1.0 \%)$, onion paste $(20.0 \%)$, cumin powder $(0.5 \%)$, spice mix (1.5\%), asafetida powder (0.5\%) and curd (25.0\%) were added over and above rice flour and goat meat combination. Significantly $(\mathrm{P}<0.05)$ increased values were observed in goat meat emulsion incorporated seasoning fryums for $\mathrm{pH}$, product yield, bulk density, moisture, protein and fat contents. Significantly $(\mathrm{P}<0.05)$ reverse trends were observed for hydratability, water absorption index and water solubility index in ground goat meat based ready to fry seasoning fryums. Results of sensory evaluation on 9 - point hedonic scale showed appearance
\end{abstract}


and colour, flavour, texture, crispness, after taste, meat flavour intensity and overall palatability were higher for goat meat emulsion incorporated seasoning fryums then ground goat meat based ready to fry seasoning fryums. Sensory evaluation results indicated that goat meat emulsion incorporated seasoning fryums were rated "very palatable" as compared to ground goat meat based ready to fry seasoning fryums. Thus, it can be concluded that, $50 \%$ goat meat emulsion and $50 \%$ rice flour can be successfully used for preparation of meat based seasoning fryums (meat vadam) of acceptable quality.

\section{Keywords — Goat, Fryums, Meat, Ready to fry, Seasoning, Quality}

\section{References:}

[1] Anderson, R.A., Coonway, B,H.F., Pfrifer,V.F. \& Griffin, E.J Jr. (1969). Gelatinization of corn grits by roll and extrusion cooking. Cereal Science Today, 14:4 - 12.

[2] Breen, M.D., Seyam, A.A. \& Banasik, O.J. (1977). The effect of mill by product and soy protein on the physical characteristics of expanded snack foods. Cereal Chemistry, 54:728 736.

[3] Cheftel, J.C. (1986). Nutritional effects of extrusion cooking. Food Chemistry, 20:263 - 283.

[4] Gomez, M.H. \& Aguilera, J.M. (1983). A physico chemical model for extrusion of corn starch. Journal of Food Science, 49:43, 63.

[5] Jean, I.J., Work, R., Camire, M.E., Briggs, J., Barrett, A.H. \& Bushway, A.A. (1996). Selected properties of extruded potato and chicken meat. Journal of Food Science, 61:783 789.

[6] Kavya Reddy, M., Aparna Kuna, Lakshmi Dev, N., Krishnaiah, N., Charanjit Kaur, \& Nagamalleswari,Y. (2014). Development of extruded Ready-To-Eat (RTE) snacks using corn, black gram, roots and tuber flour blends. Journal of Food Science and Technology, 51:1929-1937.

[7] Park, J., Rhee, K.S., Kim, B.K. \& Rhee, K.C. (1993). High protein texturized products of defatted soy flour, corn starch and beef: Shelf life, physical and sensory properties. Journal of Food Science, 58:21-27. 
[8] Rhee, K.S., Cho, S.H. \& Pradahn, A.M. (1999). Composition, storage stability and sensory properties of expanded extrudates from blends of corn starch and goat meat, lamb, mutton, spent fowl meat, or beef. Meat Science, 52: 135 - 141.

[9] Singh, P., Sahoo, J., Chatli, M.K. \& Biswas, A.K. (2014). Optimization of the level of rice flour in chicken meat caruncles. Indian Journal of Veterinary Research, 23:10 - 20. 


\title{
Bio-pesticides--a new era for control of Mealy bug (Maconellicoccus hirsutus Green) on som plant (Machilus bombycina King) and environmental sustainability
}

\author{
Sunil Kumar Ghosh* \\ Department of Agricultural Entomology, B.C.K.V-Agriculture University, Kalyani, West \\ Bengal-741235, India. \\ *E-mail: sg_bckv2014@rediffmail.com
}

\begin{abstract}
Som plant (Machilus bombycina King) is an important plant in agroforestry system. Rural developments through localized cottage industries are involved with this plant like sericulture industry (muga silk worm cultivation). Leaves of som plants are major food of muga silk worm (Antherea assama). A field experiment was conducted under Uttar Banga Krishi Viswavidyalaya (State Agricultural University) at Pundibari, Coochbehar, West Bengal, India to study seasonal occurrence of mealy bug (Maconellicoccus hirsutus Green) on som plant (Machilus bombycina King) and its management using bio-pesticides. The mealy bug was active throughout the year. The peak population of mealy bug (above 18 mealy bugs/3 leaves) was recorded on $10^{\text {th }}$ standard meteorological week i.e. on $2^{\text {nd }}$ week of March. Correlation coefficient (r) study between pest population with environmental parameter showed that there was significant positive(+)correlation with temperature difference and significant negative()correlation with temperature (minimum and average) and relative humidity (maximum, minimum and average). On the other hand non-significant negative(-)correlation found between mealy bug population and maximum temperature. Bio-efficacy of different treatments against mealy bug showed that Imidacloprid (confidor $17.8 \mathrm{SL}$ ) $1 \mathrm{ml} / 5 \mathrm{~L}$ was found superior for management of mealy bug (about $77.00 \%$ reduction of mealy bug population) followed by Azadiractin (nimarin $1500 \mathrm{ppm}$ ) $2.5 \mathrm{ml} / \mathrm{L}$ (about $57.00 \%$ reduction of mealy bug population). However among the botanical extract Tobacco was found best (more than $50.00 \%$ reduction of mealy bug population) closely followed by Garlic (above $48.00 \%$ reduction) and Spilanthes
\end{abstract}


(above $45.00 \%$ reduction) and Polygonum (above $40.00 \%$ reduction). Plant extracts are biological origin having no hazardous effect to environment and so can be incorporated in Integrated Pest Management (IPM) programme against mealy bug on som plant.

Keywords - Abiotic factors, botanical extracts, mealy bug, organic cultivation, seasonal occurrence.

\section{References:}

[1] Ghosh SK. 1999. Studies on the pest constraints of brinjal/eggplant (Solanum melongena L.) and their management under terai region of West Bengal, India. Ph.D. Thesis awarded by BCKV-Agriculture University, West Bengal, India, Pp. 43-44.

[2] Ghosh SK. 2014. Population dynamics of different species of flea beetle infesting ladysfinger (Abelmoschus esculentus L.) and their sustainable management. Journal of applied Zoological research, 25(2): 121-128.

[3] Ghosh SK. 2019. Climate impact on red spider mite (Tetranychus sp. Koch) infesting eggplant (Solanum melongena L.) and their management using plant extracts. Journal of Entomological Research, 43 (3): 345-350.

[4] Ghosh SK and Chakraborty G. 2012. Integrated field management of Henosepilachna vigintioctopunctata (Fabr.) on potato using botanical and microbial pesticides. Journal of biopesticides, 5 (supplementary): 151-154.

[5] Ghosh S K, Mahapatra G S S and Chakraborty G.2009. Field efficacy of plant extracts and microbial insecticides against aphid (Aphis gossypii) infesting okra (Abelmoschus esculentus). Redia, Itali XC11: 249-252. (with sub-title Journal of Entomology).

[6] Ghosh SK, Mandal T, Biswas S and Chakraborty K. 2012. Field evaluation of cultivars and bio-efficacy of insecticides against pest complex of ladysfinger (Abelmoschus esculentus L.). Journal of applied Zoological research, 23(2): 121-128.

[7] Ghosh SK, Mandal T and Chakraborty K. 2013. Efficacy of chemical insecticides and neem oil against white fly (Bemisia tabaci Genn.) Infesting ladysfinger (Abelmoschus esculentus L.). International Journal of Bio-resource and Stress Management, 4 (2): special 348-351. 
[8] Ghosh SK, Mandol T and Chakraborty K. 2016. Population fluctuation of aphid (Aphis craccivora Koch..) infesting Som plant leaves (Machilus bombycina King..) and its management. Journal of Entomological Research.. 40 (3): 235-241.

[9] Ghosh SK and Senapati SK. 2002. Field evaluation of pesticides from different origin against pest complex of brinjal/eggplant under terai region of W. B. Crop Reearch., 23(1): 108-115.

[10] Mandol T Ghosh SK and Chakraborty K. 2016. Seasonal incidence of thrips (Thrips tabaci L.) infesting Som plant leaves (Machilus bombycina King.) and their management using bio-pesticides. International Journal of Science, Environment and Technology, 5 (4): 2245-2256.

[11] Subba B and Ghosh SK. 2016. Population dynamics of Thrips (Thrips tabaci L.) Infesting tomato (Lycopersicon esculentum L.) and their sustainable management. International Journal of Agriculture Science. and Research. (IJASR) 6 (3): 473-480. 


\title{
Evaluation of Puf locus targeted PCR for easy identification of Saprolegnia parasitica
}

\author{
Khangembam Victoria Chanu*, Dimpal Thakuria, Vinita Pant, Sweta Bisht
}

ICAR-Directorate of Coldwater Fisheries Research, Bhimtal, Uttarakhand-263136, India.

Email: drvictoriakc@gmail.com

\begin{abstract}
Saprolegnia is a genus of oomycetes under family Saprolegniaceae and order Saprolegniales. Some members of this genus are highly virulent and are considered as one of the most destructive fish pathogen causing huge loss in aquaculture. Earlier Saprolegnia infections were controlled by use of malachite green but its use is banned due to its harmful effects. Since then, Saprolegnia infections have re-emerged and particularly $S$. parasiticahas become an economically important fish pathogen. Species identification by only morphology is difficult, so, the most common confirmatory method for identification of Saprolegnia species is sequencing of internal transcribed spacer (ITS) region. Since, sequencer is not a common facility in every laboratory and sequencing by outsourcing is again time-consuming. In this study, a PCR protocol targeting Puf locus in the genomic DNA was evaluated for easy identification of S. parasitica. The amplified product using the published primer set Puf112 and Puf310 was around 365 bp. The product was sequenced and in BLAST high similarity with $S$. parasitica hypothetical protein mRNA (XM_012354450) was observed. The sequence was submitted to NCBI GenBank (MT556640). The protocol could also detect up to few picogram genomic DNA of S. parasitica. When the protocol was tested with other species of Saprolegnia, there was no amplification enabling differentiation between $S$. parasitica and other species. Therefore, this protocol may be prove to be an easier, faster and cheaper method of molecular identification of S. parasitica as sequencing is not involved.
\end{abstract}

Keywords- Genomic DNA, PCR,Puflocus,Saprolegnia parasitica, species differentiation 


\section{References:}

[1] Fregeneda-Grandes J.M., Rodríguez-Cadenas, F., Carbajal-González, M.T. and AllerGancedo, J.M. (2007). Detection of 'long-haired' Saprolegnia (S. parasitica) isolates using monoclonal antibodies. Mycol Res.111(Pt 6):726-733.

[2] Culp, S.J., Beland, F.A., Heflich, R.H., Benson, R.W., Blankenship, L.R.,Webb, P.J., Mellick, P.W., Trotter, R.W., Shelton, S.D., Greenlees, K.J. andManjanatha, M.G. (2002). Mutagenicity and carcinogenicity in relation to DNA adduct formation in rats fed leucomalachite green. Mutation Research/Fundamental and Molecular Mechanisms of Mutagenesis. 506-507:55-63.

[3] Almeida,A., Cunha, A., Gomes, N.C.M., Alves, E., Costa, L. and Faustino, M.A.F. (2009). Phage therapy and photodynamic therapy: low environmental impact approaches to inactive microorganisms in fish farming plants. Mar.Drugs. 7:268-313.

[4] Dieguez-Uribeondo, J., Cerenius, L. and Soderhall, K. (1996). Physiological characterization of Saprolegnia parasitica isolates from brown trout. Aquaculture, 140(3): 247-257.

[5] White, T.J., Bruns, T., Lee, S.J. W.T. and Taylor, J. (1990). Amplification and direct sequencing of fungal ribosomal RNA genes for phylogenetics. PCR protocols: a guide to methods and applications, 18(1): 315-322.

[6] Spassov, D.S., and Jurecic, R. (2003). The PUF family of RNA-binding proteins: does evolutionarily conserved structure equal conserved function. IUBMB Life. 55(7): 359-366.

[7] Leung, W.L. (2012). The oomycete Saprolegnia parasitica: molecular tools for improved taxonomy and species identification. Ph. D Thesis. University of Victoria, Canada.

[8] Andersson, M.G. and Cerenius, L. (2002). Pumilio homologue from Saprolegnia parasitica specifically expressed in undifferentiated spore cysts. Eukaryotic cell, 1(1): 105-111. 


\title{
Control of Insect pests of Mung bean (Vigna radiata L. Wilczek) using Plant extracts
}

\author{
Anand Kumar Prajapat ${ }^{1}$, Lekhu Gehlot ${ }^{2}$ \\ ${ }^{1,2}$ Department of Zoology, Jai Narain Vyas University, Jodhpur; Rajasthan-342005, India \\ ${ }^{1}$ Email- akp7792@gmail.com \\ ${ }^{2}$ Email-drlekhu@rediffmail.com
}

\begin{abstract}
Mung bean or green gram, (Vigna radiata L. Wilczek) is important pulse crop. Many insect pests attack on mungbean crop and causing extremely elevated losses to the crop and its production. A field experiment was conducted during cropping season -2019 for the determining efficiency of plant extracts against insect pests of mung bean. Plant extract obtain from neem leafs (Azadirachta indica), turmeric (Curcuma longa) and cloves (Syzygium aromaticum). Experimental design was in three plots. $100 \mathrm{ml}$ of the plant extracts were used weekly. Data were collected weekly by the counting of mean population of insect pests. The results observed that the plant extracts were effective against pests of mung bean aphid (Aphis craccivora), jassid (Empoasca motti) and white fly (Bemisia tabaci). The mean population of aphid, jassid and white fly in 2019 was significantly decreased in the treated plots with plant extracts as compared to controlled plot. The population of aphid was decreased from 10.2 to 6.2, jassid population was decreased from 10.1 to 7.1 and white fly population was decrease from 14.1 to 6.3. All used plant extract have insecticidal activity against insect pests of mung bean. Therefore these plant extract can be used for the control of insect pests of mung bean.

Keywords - Aphid, Insect pest, Jassid, Mung bean, Plant extract, White fly.
\end{abstract}

\section{References:}

[1] Asawalam, E.F., Constance, E.E., (2018). Control of field insect pests of mung bean (Vigna radiata L. Wilczek) using some plant extracts in Unudike, Nigeria. Journal of Medicinal Plants for Economic Development 2(1). a27. 
[2] Dar, M.H., Rizvi, P.Q. and Naqvi, N.A. (2002). Efficacy of neem and synthetic insecticides for the management of insect-pests of green gram (Vigna radiata (L.) Wilczek). Pest Management and Economic Zoology, 10(1): 57-60.

[3] Ved, R., Massod, A., Misra, S.K. and Upadhyay, R.M. (2008). Studies on sulphur, zinc and bio fertilizers on yield and yield attributes and nutrient content at different growth stages of mungbean. J. Food Legumes, 21(4): 240-242. 


\title{
Rice yield and soil fertility status at harvest as influenced by integrated nitrogen management
}

\author{
Harish Shenoy ${ }^{1}$. and Siddaraju. M. N. ${ }^{2}$ \\ Department of Botany, University College, Mangalore, Mangalore University, Mangaluru, \\ Karnataka-572001, India. \\ E-mail id : ${ }^{1}$ harish.shenoy1@gmail.com ${ }^{2} \underline{\text { siddumn@gmail.com }}$
}

\begin{abstract}
A field investigation was carried out during Kharif-2017 at the instructional farm of ICAR-Krishi Vigyan Kendra (KVK), Mangaluru, Karnataka state, to study the effect of integration of organic and inorganic source of nitrogen on soil fertility status at harvest and yield of rice. There were eleven treatments comprising of vermicompost (VC), poultry manure (PM) and fish manure (FM) as nitrogen source of organic manure integrated with fertilizer nitrogen source of urea in proportion of 25 percent and 50 percent along with one control and treatment comprising application of recommended package of practices. The experiment was laid out in randomized block design with three replications. The results indicated that plant height, productive tillers hill ${ }^{-1}$, grain yield and straw yield were significantly influenced by integration of nitrogen management in rice. The treatment receiving 50 per cent $\mathrm{VC}$ integrated with 50 percent recommended dose of nitrogen $(\mathrm{RDN})$ recorded significantly higher plant height $(92.27 \mathrm{~cm})$, higher number of productive tillers hill-1 $(16.85)$, higher grain yield $\left(5434 \mathrm{~kg} \mathrm{ha}^{-1}\right)$ and straw yield (6817 $\mathrm{kg} \mathrm{ha}^{-1}$ ) compared to control. Soil samples collected at harvest were analyzed for soil fertility parameters. The results indicated that soil $\mathrm{pH}$ and Electrical Conductivity (EC) were not significantly influenced by integration of organic and inorganic sources of nitrogen. However, the major nutrients were significantly influenced by integrated nitrogen management. The available nitrogen was significantly higher in the treatment of receiving 50 per cent $\mathrm{VC}$ integrated with 50 per cent RDN (382.36 $\left.\mathrm{kg} \mathrm{ha}^{-1}\right)$ compared to control $\left(294.05 \mathrm{~kg} \mathrm{ha}^{-1}\right)$. The available soil phosphorus was significantly higher in treatment receiving 50 per cent PM integrated with 50 per cent $\operatorname{RDN}\left(78.83 \mathrm{~kg} \mathrm{ha}^{-1}\right)$ compared to control $\left(43.93 \mathrm{~kg} \mathrm{ha}^{-1}\right)$. The
\end{abstract}


available potassium was significantly higher in the treatment receiving 50 per cent $\mathrm{VC}$ integrated with 50 per cent $\operatorname{RDN}\left(143.7 \mathrm{~kg} \mathrm{ha}^{-1}\right)$ compared to control $\left(92.31 \mathrm{~kg} \mathrm{ha}^{-1}\right)$.

\section{Keywords— Fish manure, Poultry manure, Rice, Soil fertility, Vermicompost.}

\section{References:}

[1] Dekhane, S. S., Patel, D. J., Jadhav, P. B., Kireeti, A., Patil, N. B., Harad, N. B. and Jadhav, K. P. (2014). Effect of organic and inorganic fertilizer on growth and yield of paddy cultivar GR-11. International Journal of Information Research and Review, 1(2), 026-028.

[2] Gobi R, S., Shanmuga Sundaram, A. Balasubramanian and D .Elayaraja (2018). Effect of integrated nutrient management on nutrient uptake and nitrogen use efficiency in lowland rice, Advances in Plant Sciences, 31(2),113-115.

[3] Kavitha C and Sujatha. M.P (2015). Evaluation of soil fertility status in various agro systems of Thrissur district, Kerala, India. International Journal of Agriculture and Crop Sciences, 8(3): 328-338.

[4] Kumar, A. N. Meena, Lalji Y. and Y. K. Gilotia (2014) Effect of organic and inorganic sources of nutrient on yield, yield attributes and nutrient uptake of Rice cv. PRH-10, The Bioscan 9(2),595-597.

[5] Nagaraj R , M. Hanumanthappa and K .V. K. Sudhir(2020), Integrated Nutrient Management in paddy in coastal zone of Karnataka India. International Journal of Current Microbiology and Applied Sciences 7(06),1745-1753.

[6] Prasad. R , Pathak H., Patra A K., and Shivay Y S (2014). Nitrogen Management . In Prasad R, Kumar. D, Rana D. S., Shivay. Y.S.and Tewatia. R. K. A Text book of Plant Nutrient Management (pp.73-92) Indian Society of Agronomy,IARI, New Delhi.

[7] Prathap Reddy, N.C H. Bharat Bhushan Rao, K.Surekha and Hussain, S.A (2019). Transplanted Rice as Influenced by Different Enriched Nitrogen Sources-an Economic Appraisal. International Journal of Current Microbiology and Applied Sciences 8 (06): 3229-3231. https://doi.org/10.20546/ijcmas.2019.806.384 
[8] Surekha K R, Mahendra Kumar V, Nagendra N, Sailaja T, Satyanarayana, (2016). 4R nitrogen management for sustained rice production Better Crops-South Asia 8 (10), 18 19. 


\title{
Chemical composition of essential oils of Rhus tripartita in Algeria
}

Benlembarek Khaoula*, Lograda Takia, Ramdani Messaoud and Belguidoum Amina

Laboratory of Valorization of Natural and biological Resources, SNV Faculty, Ferhat Abbas

\author{
University Setif-1, Algeria.
}

*Corresponding author: benkhaoula72@yahoo.com

\begin{abstract}
The aim of this work is the study of the chemical composition of the populations of Rhus tripartita in Algeria. The aerial parts of $R$. tripartita were collected in the flowering stage from seven localities in East Algeria and subjected to hydro-distillation to extract the essential oils. The chemical composition of the oils was determined by Gas chromatography/ mass spectrometry (GC / MS) analysis. The yield of $R$. tripartita essential oils was low with an average of $0.16 \pm 0.017$. The $\alpha$-pinene $(58.72 \pm 14.45 \%), \Delta 3$-carene $(5.21 \pm 6.89 \%)$, caryophyllene-Z $(4.55 \pm 4.68 \%)$ and $\beta$-pinene $(3.07 \pm 185 \%)$ are the major components of the oils. The results reveal a notable difference between the chemical composition of essential oils from male and female populations. The Statistical analyzes using principal component analysis and UPGMA have allowed to identify four chemotypes in $R$. tripartita essential oils: the $\Delta 3$ carene- $\alpha$-pinene-limonene chemotype characterizes the male populations of Tamnrasset and Boussaada. The $\alpha$-pinene- $\Delta 3$-carene-caryophyllene- $Z$ chemotype characterizes the populations of M'sila and Mergueb male. The female M'sila population is characterized by the $\alpha$-pinene- $\Delta 3$ carene- $\Delta$-cadinene chemotype. The remaining populations show the $\alpha$-pinene- $\beta$-pinenecaryophyllene-Z chemotype.
\end{abstract}

Keywords - Rhus tripartita, essential oils, chemotypes, Algeria.

\section{References:}

[1] Adams, R.P., 2007. Identification of Essential Oil Components by Gas Chromatography/Mass Spectrometry, 4th Ed. Allured Publishing Corporation, Illinois. 
[2] Farag, M.A., Fayek, N.M., Abou Reidah, I., 2018. Volatile profiling in Rhus coriaria fruit (sumac) from three different geographical origins and upon roasting as analyzed via solidphase microextraction. PeerJ. 6, 1-16. Doi: 10.7717/peerj.5121

[3] Furth, D.G., Connecticut Academy of Arts and Sciences., 1985. The natural history of a sumac tree, with an emphasis on the entomofauna. Archon books., Hamden, pp. 137-234.

[4] Giovanellia, S., Giusti, G., Cioni, P., Minissale, P., Ciccarelli, D., Pistelli, L., 2017. Aroma profile and essential oil composition of Rhus coriaria fruits from four Sicilian sites of collection. Industrial Crops and Products. 97, 166-174. Doi:10.1080/10412905.2014.882278

[5] Idm'hand, E., Msanda, F., Cherifi, K., 2019. Searsia tripartita (Ucria) Moffett : phytochimie, pharmacologie et usages traditionnels. Phytothérapie, 1-5. Doi: 10.3166/phyto$\underline{2019-0167}$

[6] Kurucu, S., Koyuncu, M., Güvenç, A., Baser, K.H.C., Özek, T., 1993. The Essential Oils of Rhus coriaria L. (Sumac), Journal of Essential Oil Research. 5(5), 481-486. Doi: $10.1080 / 10412905.1993 .9698267$

[7] Lee, S.K., Jung, H.S, Eo, W.K., Lee, S.Y., Kim, S.H., Shim, B.S., 2010. Rhus verniciflua stokes extract as a potential option for treatment of metastatic renal cell carcinoma: Report of two cases. Annals of Oncology. 21(6), 1383-1385. Doi: 10.1093/annonc/mdq154

[8] Masada, Y., 1976. Analysis of essential oils by Gas Chromatography and Mass Spectrometry. John Wiley \& Sons, New York.

[9] Morshedlooa, M.R., Maggi, F., Neko, H.T., Aghdam, M.S., 2017. Sumac (Rhus coriaria L.) fruit: Essential oil variability in Iranian populations. Industrial Crops \& Products. 111, 1-7. Doi: http://dx.doi.org/10.1016/j.indcrop.2017.10.002

[10] NIST., 2002. Mass Spectral Search Program for the NIST/EPA/NIH Mass Spectral Library, vers, 2.0, fiveash data, USA

[11] Quézel, P., Santa, S., 1962. Nouvelle Flore de l'Algérie et des régions désertiques Méridionales. 2 Vol. C.N.R.S, Paris.

[12] Ridel, R.V.B., Cioni, P.L., Majo, L., Pistelli, L., 2017. Evolution of Volatile Emission in Rhus coriaria Organs during Different Stages of Growth and Evaluation of the Essential Oil Composition. Chemistry \& Biodiversity. 14(11), 1-12. Doi: 10.1002/cbdv.201700270 
[13] Saadatian, M., Aghaei, M., Farahpour, M., Balouchi, Z., 2013. Chemical composition of lavender (Lavandula officinallis L.) extraction extracted by two solvent concentrations. Global Journal of Medicinal Plant Research. 1(2), 214-217. http://www.aensiweb.com/old/GJMPR/2013/214-217.pdf

[14] Sangwan, NS., Farooqi, A.H.A., Shabih, F., Sangwan, RS., 2001. Regulation of essential oil production in plants. Plant Growth Regul. 34, 03-21. Doi: 10.1023/A:1013386921596

[15] Wu, T., Callum, J.L., Wang, S., Liu, R., Zhu, H., Tsao, R., 2013. Evaluation of antioxidant activities and chemical characterisation of staghorn sumac fruit (Rhus hirta L.). Food Chemistry. 138(2-3), 1333-1340. Doi: https://doi.org/10.1016/j.foodchem.2012.10.086

[16] Zhaleh, M., Sohrabi, N., Zangeneh, M., Zangeneh, A., Moradi, R., Zhaleh, H., 2018. Chemical Composition and Antibacterial Effects of Essential Oil of Rhus coriaria Fruits in the West of Iran (Kermanshah). Journal of Essential Oil Bearing Plants. 21(2), 493-501. Doi: 10.1080/0972060X.2018.1462739 


\title{
Biomonitoring of metal trace elements by epiphytic lichen Xanthoria parietina in Bejaia area (Northern Algeria)
}

\author{
Belguidoum Amina, Logradatakia, Benlembarek Khaoula, and Ramdani Messaoud \\ Laboratory for Valorization of Natural biological Resources, SNV Faculty, Ferhat Abbas \\ * Corresponding author: belguidoum.amina@yahoo.com
}

\begin{abstract}
The metallic air pollution in the Bejaia region (northern Algeria) were examined, using the lichen Xanthoria parietina as a bio-monitoring organism. The biological material from 42 stations were sampled and analyzed by flame atomic absorption spectrophotometry (AASF). In order to determine the relationship between the potential sources of contaminants in the study area and the degree of deposition of metals in the air, five heavy metals $(\mathrm{Cd}, \mathrm{Cu}, \mathrm{Pb}, \mathrm{Mn}$, and $\mathrm{Ag}$ ) were analyzed. The results show that the metal contents recorded in the various sampled stations are fluctuating and lead to the following decreasing series: $\mathrm{Pb}>\mathrm{Mn}>\mathrm{Cu}>\mathrm{Ag}>\mathrm{Cd}$. The air quality in the town of Amizour is considerably poor compared to the rest of the studied stations. The $\mathrm{Pb}$ and $\mathrm{Mn}$ levels are very high in all stations with an average of (134.62 \pm 148.53 $\mathrm{mg} / \mathrm{kg}$ and $290.88 \pm 175.13 \mathrm{mg} / \mathrm{kg}$ ) respectively. The highest concentrations of heavy metals were observed around the municipalities of Bejaia, Akbou and Tichy. The current situation suggests an obvious need to mitigate atmospheric pollution by MTE and to control the emissions of toxic metals, in particular $\mathrm{Pb}$ from agricultural activities, industrial sources and road traffic in large cities.
\end{abstract}

Keywords - Biomonitoring, Bioaccumulation, heavy metals, Xanthoria parietina, Bejaia, Algeria.

\section{References:}

[1] Adjiri, F., Ramdani, M., Lograda, T., Chalard, P. 2018. Bio monitoring of metal trace elements by epiphytic lichen in the Bordj Bou Arreridj area, east of Algeria. Scholars Academic Journal of Biosciences, 6(2), 199-208. DOI: 10.21276/sajb.2018.6.2.12 
[2] Balabanova, B., Stafilov, T., Sajn, R., Baceva, K. (2012). Characterisation of heavy metals in lichen species Hypogymnia physodes and Evernia prunastri due to biomonitoring of air pollution in the vicinity of copper mine. International Journal of Environmental Research, 6(3), 779-794. http://eprints.ugd.edu.mk/id/eprint/5060

[3] Demková, L., Árvay, J., Bobul'ská, L., Hauptvogl, M., Hrstková, M. (2019). Open mining pits and heaps of waste material as the source of undesirable substances: biomonitoring of air and soil pollution in former mining area (Dubnik, Slovakia). Environmental Science and Pollution Research, 26(34), 35227-35239. doi: 10.1007/s11356-019-06582-0

[4] Garty, J. (2001). Biomonitoring atmospheric heavy metals with lichens: theory and application. Critical reviews in plant sciences, 20(4), 309-371. https://doi.org/10.1080/20013591099254

[5] Kresovich, J. K., Erdal, S., Chen, H. Y., Gann, P. H., Argos, M., Rauscher, G. H. (2019). Metallic air pollutants and breast cancer heterogeneity. Environmental research, 177, 108639.DOI: $10.1016 /$ j.envres.2019.108639

[6] Nimis, P. L., Lazzarin, G., Lazzarin, A., Skert, N. (2000). Biomonitoring of trace elements with lichens in Veneto (NE Italy). Science of the total environment, 255(1-3), 97-111. https://doi.org/10.1016/S0048-9697(00)00454-X

[7] Liu, H. J., Fang, S. B., Liu, S. W., Zhao, L. C., Guo, X. P., Jiang, Y. J., Liu X. D., Xia Y., Wang Y. D., Wu, Q. F. (2016). Lichen elemental composition distinguishes anthropogenic emissions from dust storm inputs and differs among species: Evidence from Xilinhot, Inner Mongolia, China. Scientific reports, 6, 34694. DOI: 10.1038/srep34694

[8] Liu, H. J., Zhao, L. C., Fang, S. B., Liu, S. W., Hu, J. S., Wang, L., Liu X. D, Wu, Q. F. (2016). Use of the lichen Xanthoria mandschurica in monitoring atmospheric elemental deposition in the Taihang Mountains, Hebei, China. Scientific Reports, 6, 23456. DOI: $\underline{10.1038 / \text { srep23456 }}$ 